\title{
MÃE E A INVENÇÃO DA FAMÍLIA: UMA LEITURA PSICANALÍTICA DO ROMANCE O FILHO DE MIL HOMENS COMO UM CONTRAPONTO AO ESTATUTO DA FAMÍLIA
}

\author{
Humberto Moacir de Oliveira ${ }^{1}$
}

RESUMO: Em 2013 a Câmara dos Deputados apresentou um projeto de lei que dispunha sobre o Estatuto da Família. O projeto, aprovado em Comissão Especial em 2015, aguarda, até o presente momento, votação no plenário. O Estatuto provocou muitas querelas, principalmente em torno de sua estreita definição de entidade familiar, que em alguns trechos se limita a união conjugal firmada entre um homem e uma mulher. Em 2012, um ano antes de o projeto ser apresentado na Câmara, chegou ao Brasil o livro O filho de mil homens, quinto romance de Valter Hugo Mãe. A obra traz como um dos seus temas principais a invenção de uma família e expõe, através dela, como o laço afetivo muitas vezes participa mais do engendramento do núcleo familiar do que laços sanguíneos ou disposições de gêneros. O presente artigo pretende fazer uma leitura psicanalítica do romance de Mãe apresentando-o como um contraponto à definição de entidade familiar proposta pelo Estatuto da Família, já que para a teoria psicanalítica, assim como revela também a prosa de Mãe, o conceito de família abarca um arranjo muito mais complexo do que o Estatuto busca delimitar.

PALAVRAS-CHAVE: O filho de mil homens, Valter Hugo Mãe, psicanálise, entidade familiar.

\section{MÃE AND THE INVENTION OF FAMILY: A PSYCHOANALYTICAL READING OF THE NOVEL O FILHO DE MIL HOMENS (THE CHILD OF A THOUSAND MEN) AS A COUNTERPOINT OF THE BRAZILIAN FAMILY CODE}

ABSTRACT: In 2013, the Brazilian Chamber of Deputies presented a bill establishing the Family Code. The bill, approved in 2015 by an Especial Commission, has been awaiting to be voted up to the present moment. The Code provoked plenty of dispute, mainly around its straight definition of family entity which in some parts is limited to the conjugal union between a man and a woman. In 2012, one year before the bill being presented in the Chamber of Deputies, the book "O filho de mil homens" (The child of a thousand men), the fifth novel by Valter Hugo Mãe, arrived in Brazil. The novel has as its main themes the invention of a family and exposes through this family how emotional ties very often take a larger part in engendering the family nucleus than blood ties or gender standards. This given article intends to make a psychoanalytical reading of Mãe's novel, presenting it as a counterpoint to the definition of family entity proposed by the Brazilian Family Code, once in the psychoanalytical theory, as well as in Mãe's prose, family embraces a much more complex arrangement than the Code intends to delimit.

KEYWORDS: The child of a thousand men; Valter Hugo Mãe, psychoanalysis, family entity.

Introdução

Em outubro de 2013 começou a tramitar na Câmara dos Deputados o projeto de lei número 6583/13, referente ao controverso Estatuto da Família. O projeto, proposto pelo

\footnotetext{
${ }^{1}$ Professor da Faculdade Pitágoras de Ipatinga. Mestre em Psicologia pela UFMG. Coordenador do CEPP (Centro de Estudo e Pesquisa em Psicanálise do Vale do Aço). ORCID: http://orcid.org/0000-0003-33386774 URL: http://lattes.cnpq.br/9504791523456026
} 
deputado Anderson Ferreira (PR-PE), foi aprovado em Comissão Especial, mas aguarda, desde 2015, votação no plenário. O Estatuto traz, em seu segundo artigo, a definição de entidade familiar proposta nos seguintes termos: "núcleo social formado a partir da união entre um homem e uma mulher, por meio de casamento ou união estável, ou ainda por comunidade formada por qualquer dos pais e seus descendentes” (BRASIL, 2013, p.1). O projeto se justifica dizendo que o Estado, que deveria proteger a família, "não apresenta políticas públicas efetivas voltadas especialmente à valorização da família e ao enfrentamento das questões complexas a que estão submetidas as famílias num contexto contemporâneo” (BRASIL, 2013, p.6). Dentre as questões complexas citadas está a "desconstrução do conceito de família". E o projeto reafirma logo em seguida qual conceito deveria ser fortalecido, a saber, "união conjugal firmada entre o homem e a mulher" (BRASIL, 2013, p.7).

A proposta claramente visa limitar o conceito de família a partir de preconceitos em relação à homossexualidade, à identidade de gênero, entre outros. Os que defendem tal Estatuto acabam por endossar um velho discurso que pretende fazer crer que a família está sempre na eminência de se extinguir. Diante da legalização do divórcio, do voto feminino, da discussão sobre a legalização do aborto e de certas drogas, da emancipação das mulheres, da adoção de crianças por pais homossexuais, ou mesmo do simples relacionamento homossexual (sem que haja sequer uma constituição de família) sempre houve quem dissesse que a família estaria ameaçada. Ao menor sinal de avanço nas liberdades individuais, surgem discursos apocalípticos que servem como um alerta do tipo: “cuidado, a família está em risco". Ela, tantas vezes ela, a família, ou por vezes a chamada "tradicional família brasileira", estaria a um passo de se extinguir.

Um ano antes do referido projeto de lei ser apresentado, chegou ao Brasil O filho de mil homens, quinto romance de Valter Hugo Mãe, escritor nascido em Saurino, Angola, mas radicado, já há alguns anos, em Portugal. O livro, publicado em 2011 em terras portuguesas, traz como um dos seus temas principais a invenção de uma família e expõe, através dela, como o laço afetivo muitas vezes participa mais do engendramento do núcleo familiar do que os laços sanguíneos ou disposições de gêneros, como exposto no projeto de lei. No romance, podemos acompanhar a história de várias personagens solitárias que "caem para dentro de si”, em um isolamento e exclusão social dilacerantes que os levam, quase sempre, a caminhar pela marginal da vila em que vivem. No entanto, à medida que a 
história avança, essas histórias se entrelaçam e o que temos no final é mais do que uma história de superação ou de amor, mas, com anunciado pelo narrador, assistimos à invenção de uma família.

A arte pode se apresentar como um contraponto importante e necessário à visão fechada que os burocratas tendem a adotar para fabricarem nossas leis. Nesse sentido, o livro nos apresenta a possibilidade de acompanhar, através da ficção e dos afetos que ela mobiliza, a construção de uma família, ou mesmo sua invenção, ampliando o debate sobre quais seriam os fundamentos da família, sua definição e o verdadeiro risco - ou não - de ela se extinguir por conta de uma elasticidade na forma de compreendê-la. Nessa perspectiva, um debate sobre a história do romance de Mãe pode contribuir com as discussões desencadeadas pelo projeto de lei de Anderson Ferreira e enriquecer a percepção que a sociedade tem do conceito de família. Com esse objetivo, serão usadas como base teórica da discussão reflexões psicanalíticas sobre a sociedade, a felicidade, o amor e a família.

"Ser o que se pode" ou "Ser o que não se pode", eis uma questão para a felicidade

A história se passa em uma vila, no interior de Portugal. A identidade do local é omitida de forma a fazê-lo servir mais facilmente a qualquer vila, aldeia ou cidade que o leitor conheça. A vila, aliás, como bem notou Fagner Costa e Silva (2017), se estrutura como uma personagem em si, uma personagem que se mistura ao narrador compartilhando com ele, principalmente na primeira metade do livro, preconceitos e julgamentos morais que pesam sobre seus habitantes. Tanto a vila como o narrador apresentam uma visão bastante limitada sobre as possibilidades de existência das mulheres, dos homens, da família e do amor. Ambos parecem entender que apenas umas poucas formas de ser feliz seriam possíveis e aceitáveis e, por isso, condenam quaisquer outras vias de felicidade que não façam parte dos códigos morais da vila.

No entanto, como tantas vezes acontece, as personagens, buscando a felicidade a partir dos regulamentos sociais propostos pela vila e pelo narrador, frustram-se absurdamente; apostando na subversão dessas regras sociais é que conseguem ser felizes. Não por acaso, a definição de felicidade inicialmente ofertada por uma das personagens, 
"Ser o que se pode é a felicidade" (MÃE, 2016, p.86) é tensionada por outra personagem que percebe que "seria feliz quem se tornasse no que não podia” (MÃE, 2016, p.110).

A tensão entre as definições das duas personagens revela a complexidade do problema da felicidade. "Poder" aparece no texto como um termo ambíguo, ora representando uma permissão da vila, por exemplo, ser o que a vila autoriza, ora representando uma condição do sujeito, "um homem maricas não podia deixar de o ser" (MÃE, 2016, p.108). Também a palavra "ser" carrega certa ambiguidade, representando tanto o que se é enquanto sujeito de desejo, quanto o que se é exclusivamente no campo do Outro, por exemplo, um monstro, adjetivo usado pela vila para descrever os que fogem à sua visão limitada e preconceituosa.

Independentemente do significado que atribuímos às palavras e aos aforismos sobre a felicidade, o fato é que o livro vai nos preparando para uma virada, de pessoas que buscam a felicidade na aceitação do destino que a vila lhes reservou para pessoas que conseguem inventar um novo caminho singular de felicidade, transformando-se no que não se podia ser (pelo menos na visão da vila). Mas isso não acontece como uma salvação individual e solitária, em uma espécie de ruptura do laço social. Pelo contrário, é justamente o enlaçamento das vidas das personagens que permite que cada uma delas invente um lugar e uma forma para o seu desejo, para o seu amor e para a sua satisfação. O que revela que mesmo para ser o que não se pode (o que é repreendido pela vila), é necessário que se construa com o Outro um lugar possível para se ser.

Essa dinâmica relaciona-se com o paradoxo demonstrado por Freud (1996/1930) em relação ao problema da felicidade, um dos principais temas de reflexão de $O$ mal-estar na civilização. No texto freudiano, o problema da felicidade encontra seu paradoxo quando articulado com o problema da civilização. Se por um lado a civilização surge para possibilitar uma maior chance de felicidade a seus integrantes, por outro, a civilização é apresentada por Freud como um dos maiores obstáculos à felicidade humana. Se, por um lado, isolar-se socialmente aparece como uma das tantas formas de busca por felicidade apresentadas no texto freudiano, o mesmo texto revela que a felicidade depende extremamente do laço social.

No romance de Mãe, que também traz uma reflexão extremamente importante sobre o tema da felicidade, apresentando, como lembra Beuttenmuller (2012), várias definições para ela, cada personagem parece ter sua felicidade impedida pelo arranjo social 
da vila. Por não se adequarem aos regulamentos sociais da comunidade que habitam, eles não podem ser felizes, mas só conseguem desprezar tais regulamentos a partir do momento em que suas vidas se entrelaçam.

Os próprios objetivos da civilização sugeridos por Freud (1996/1930), a saber, proteger a humanidade dos perigos da natureza e regular os relacionamentos mútuos entre os seres humanos (ou seja, proteger os seres humanos deles mesmos), demonstram que os laços sociais são para o homem ao mesmo tempo perdição e redenção. Os Outros são, remendando Sartre ${ }^{2}$ (2009), nosso inferno, mas também nosso paraíso. Pois, se a civilização serve para regular os modos de satisfação dos seus membros, isso significa que ela exigirá uma certa renúncia pulsional que frustrará o sujeito por um lado, mas que o protegerá por outro. O próprio Freud reconhece que a principal fonte de sofrimento humano é "a inadequação das regras que procuram ajustar os relacionamentos mútuos dos seres humanos na família, no Estado e na sociedade" (FREUD, 1996/1930, p.93), aspecto exibido quase que caricaturalmente pelo romance de Mãe, cujas personagens principais, como será visto, padecem quase todas de uma inadequação das regras da vila.

Por outro lado, o mesmo Freud (1996/1930) salienta que os psicanalistas não são inimigos da civilização, indicando que nada em seu ensaio aponta para o fim da cultura ou para uma busca de felicidade que exclua o laço social. Não se trata de ser inimigo da civilização, nem de tentar abolir toda e qualquer regulação civilizatória dos laços humanos, mas de propor mudanças nas organizações sociais que possibilitem uma maior tolerância a variados modos de satisfação, para que mais sujeitos caibam na civilização. Como o próprio Freud sugere, após tecer duras críticas à civilização, "podemos esperar efetuar, gradativamente, em nossa civilização, alterações tais que satisfaçam melhor nossas necessidades e escapem às nossas críticas” (FREUD, 1996/1930, p.120). Alterações que no romance de Mãe, se não acontecem na vila em geral, acontecem pelo menos no núcleo principal, que parece tolerar cada vez mais diversificadas formas de satisfação e variadas formas de vida, reforçando a flexibilização indicada por Freud que permite a cada um descobrir e inventar sua própria felicidade, principalmente quando lembramos que para o psicanalista vienense, a felicidade constitui um problema singular de economia da libido,

\footnotetext{
${ }^{2}$ Sartre termina sua peça Entre quatro paredes com a reflexão trágica de Garcin: "Então, é isto o inferno. Eu não poderia acreditar... Vocês se lembram: enxofre, fornalhas, grelhas... Ah! Que piada. Não precisa de nada disso: o inferno são os Outros" (SARTRE, 2009, p.125).
} 
não havendo para tal uma regra que se aplique a todos: "Todo homem tem de descobrir por si mesmo de que modo específico ele pode ser salvo (FREUD, 1996/1930, p.91).

Dessa forma, O filho de mil homens pode ser lido como uma luta das personagens em busca de uma acomodação possível no campo do Outro para os seus modos de existir e de desejar ou satisfazer, luta essa que Freud considera uma das principais batalhas da humanidade:

Grande parte das lutas da humanidade centralizam-se em torno da tarefa única de encontrar uma acomodação conveniente entre essa reivindicação do indivíduo [reivindicação de liberdade individual] e as reivindicações culturais do grupo (FREUD, 1996/1930, p.102).

As personagens de Mãe vão, cada uma a seu modo, buscando e inventando uma forma de serem salvas, sendo "o que se pode", sendo "o que não se pode", ou construindo uma forma de poder ser o que antes não se podia, mas sempre expandindo sua existência para além das recomendações tradicionais da vila, o que inclui a maneira como cada um vive e experimenta o amor, o desejo, o gozo, a existência, mas também a família que juntos inventam.

Os que caíam para dentro de si

A primeira personagem apresentada no livro é Crisóstomo, um pescador que chega aos quarenta anos sem filhos. O desejo de ter um filho é compensado de forma bastante pueril, como também acontece em outras partes do romance. Crisóstomo compra um boneco na feira e o chama de "meu filho". Além disso, sai perguntando se sabem de alguma criança que o desejaria como pai, como se em algum lugar houvesse uma criança perdida que preenchesse o vazio de seu ser, já que ele julgava existir apenas pela metade. Certo de que encontraria a metade de tudo o que lhe faltava, o narrador descreve com poesia a relação de Crisóstomo com o objeto de seu desejo que, como concordaria Freud (1996/1905, p.210), não é um objeto com o qual buscamos encontrar, mas, sim, reencontrar, por ser experimentado como um pedaço de nós que nos foi arrancado: "Ele sentia como se procurasse uma criança que lhe pertencesse, e como se a tivesse perdido algures num passeio por distração e faltasse apenas reencontrá-la”. (MÃE, 2016, p.21).

Crisóstomo, embora carregue a marca da solidão e da puerilidade, presente também em outras personagens, pode ser considerado uma exceção entre o núcleo principal do 
romance. Em que pese algumas inocências zombadas por alguns habitantes da vila e pelo narrador, como conversar com a natureza e chamar um boneco de filho, Crisóstomo não apresenta nenhuma característica muito condenada pela moral tacanha da vila. Assim, acaba sendo esse sujeito, um pescador em busca de uma companhia verdadeira, "aquela que não tinha por que ir embora e, se fosse, ir embora significaria ficar ali, junto" (MÃE, 2016 p.23), um dos elos principais tanto da felicidade encontrada por cada um como da invenção da família apresentada no fim do romance.

Mas, inicialmente, mesmo sem sofrer demasiadamente com os preconceitos da vila, Crisóstomo é apresentado, como as demais personagens também o serão, como um homem que caía para dentro de si: "Para dentro do homem era um sem fim, e pouco ou nada do que continha lhe servia de felicidade. Para dentro do homem o homem caía" (MÃE, 2016, p.19). Essa poética imagem da solidão será usada também para desenhar outras personagens da trama, sujeitos que nada têm que lhes sirvam de felicidade, sujeitos que tombam para dentro de si em uma solidão profunda que abre uma fenda entre eles e o Outro.

No entanto, Crisóstomo, após fazer um pedido ingênuo à natureza, conhece o menino órfão Camilo e encontra, ou reencontra, a metade de tudo o que lhe faltava: um filho. Camilo é um menino de 14 anos, descrito também como um rapaz que para dentro do rapaz caía. Era filho de uma anã, habitante de outra vila, que todos consideravam fraca e que merecia mais piedade do que qualquer pessoa. Camilo fica órfão logo em seu nascimento. A anã, que para espanto e frustração da piedade das vizinhas, havia deitado com quase todos os homens da vila, não sabe quem é o pai de Camilo. Morta no parto, não consegue tempo para os primeiros cuidados da criança e nem para uma investigação que desembocasse na reinvindicação de um pai para aquele que ficou conhecido como "o filho de quinze homens", pois quinze eram as possibilidades de sua paternidade. Camilo é, então, entregue a um velho viúvo que, ao morrer quando o rapaz tinha 14 anos, o faz órfão novamente.

Crisóstomo encontra Camilo nessa segunda orfandade. O pescador pergunta ao rapaz se ao invés de um emprego no barco ele não preferia continuar na escola, e se ao invés da solidão, não preferia se tornar seu filho. O menino aceita e logo é visto pela comunidade como legítimo filho de Crisóstomo, havendo gente que julgava que fossem pai e filho desde sempre. Crisóstomo, assim, sente-se não mais uma metade, mas um homem 
inteiro. No entanto, talvez desconfiando dos perigos de servir de objeto absoluto de um Outro, Camilo pede ao pai que deseje mais, que não se sinta inteiro com um filho, mas que busque também uma mulher, um amor. Crisóstomo inicialmente recusa, mas depois cede, não porque não se sinta inteiro, mas porque Camilo o convence de que com uma mulher poderia ser mais do que inteiro, poderia ser o dobro.

É nesse contexto que Isaura aparece. Crisóstomo, à procura de uma mulher, avista a moça a conversar com a natureza como ele mesmo fazia. Mas a moça, que contava nesse momento com seus trinta anos, já havia, aos dezesseis, sido condenada pelos pais, pelo namorado e pela vila por perder a virgindade. A despeito dessa primeira relação pré-nupcial ter sido com o próprio homem para quem era prometida, Isaura, ao deixar de ser virgem, passou a ser vista com desconfiança e foi rejeitada pelo noivo, o que lhe rendeu o epíteto de "mulher enjeitada". Novamente a marca da solidão é ressaltada: "Para dentro da Isaura era um sem fim e pouco do que continha lhe servia para felicidade. Para dentro da Isaura a Isaura caía” (MÃE, 2016, p.69). Além da solidão, Isaura carrega, com força mais evidente do que Crisóstomo, a condenação pelos preconceitos da vila. A personagem, que acreditava que o caminho para liberdade estava no casamento, acaba se frustrando pela rejeição amorosa e se deprime. Desinveste então de qualquer cuidado estético, vive uma vida sem vida e chega a tornar-se anoréxica: "Cortou o cabelo e ficou feia (...) Não comia, não queria mais ser gorda (...) Não queria ser ninguém (...) Queria diminuir até ser nada” (MÃE, 2016, p.59).

Aos trinta anos, uma semana após a morte de seu pai, Isaura decide, seguindo o apelo da mãe, casar-se com um "homem maricas" que lhe rondava. Um casamento descrito como repugnante, devido a homossexualidade do marido, mas ainda assim entendido pelos olhares machistas do narrador e da vila como uma saída sensata e segura para uma mulher enjeitada: "Por mais maricas que fosse, seria semelhante a um homem capaz de proteger a Isaura nos sustos de cada dia" (MÃE, 2016, p.63). No entanto, Antonino, a personagem descrita como "homem maricas", abandona Isaura uma noite após o casório, deixando-a cair ainda mais para dentro si. Crisóstomo a encontra um mês após esse segundo grande susto e, embora estivesse por demais desiludida, Isaura ainda não havia perdido integralmente a capacidade de amar:

Amanhecera vazia, sem ninguém dentro de si mesma, e foi como se encheu com a ideia de afinal ser impossível esquecer o amor. Porque o amor era espera e ela, sem mais nada, apenas esperava. A Isaura sabia 
que amava alguém por vir, amava a abstração de alguém no futuro (MÃE, 2016, p.69).

Crisóstomo encontra Isaura e, após certo flerte, começa a ocupar esse lugar da abstração para onde se dirigia o amor da jovem. No entanto, no exato momento em que "a mulher enjeitada" sonha pela terceira vez com um enlace amoroso, o "homem maricas", seu marido de um dia, reaparece chorando e pedindo abrigo.

Descrito inicialmente apenas como o "homem maricas", Antonino é finalmente apresentado. A narração da sua história, como frequentemente acontece, permite que o leitor compreenda e mesmo amenize a vilania do abandono que tanto martirizou Isaura. O que se segue no romance é uma apresentação didática do aforismo de Wendy Brown: "Um inimigo é alguém cuja história não se ouviu” (BROWN, 2006, citado por ZIZEK, 2014, p.49). Ouvir a história de Antonino ajuda a criar um ambiente de empatia entre o leitor e a personagem e demonstra que o dito "homem maricas" é tanto vítima dos preconceitos da vila quanto "a mulher enjeitada". Fica evidente também que a ferida por ele aberta no peito de Isaura é mais fruto de seu sofrimento do que de qualquer espécie de maldade, fato esse reconhecido pela própria Isaura, que acaba decidindo permanecer ligada ao "marido", mesmo já havendo conseguido anular o casamento na igreja. Isaura, como possivelmente acontece com muitos leitores, ao escutar o sofrimento de Antonino, substitui seu ódio por algum sentimento favorável: "Era um compromisso diferente, esse de sentir-se ligada a alguém apenas pela moral e não pelos papéis. Estava ligada pela compaixão” (MÃE, 2016, p.122).

Antonino, apresentado como delicado desde terna idade, cresceu sob o peso do ódio que a vila direcionava aos homossexuais. Vizinhos recomendam que Matilde, sua mãe, o mate. Contam histórias violentas de como outros pais lidaram com seus filhos "maricas": "Uns racharam os filhos ao meio, outros mandaram-nos embora espancados e sem ordens para voltar, e um homem até subiu pelo cu acima do filho uma vara grossa e pô-lo ao dependuro para todos verem" (MÃE, 2016, p.98). A mãe, responsável única pela educação da criança, já que o pai morrera cedo, o poupa. Como ela mesmo nota, o poupa não exatamente por odiá-lo menos, mas por conta de algum amor sempre estar presente, mesmo quando o ódio a queimava. Mas isso não livra o jovem de outras agressões físicas. 
Certa feita, como acontece também com muitos homossexuais brasileiros ${ }^{3}$, Antonino foi espancado por um grupo de homens que o acusaram, injustamente, de espioná-los no banho de mar. O jovem cresceu imerso na culpa e no ódio a si mesmo, empreendendo uma grande luta para ser o que não era: "Haveria de, renunciando à sua própria natureza, ser um herói de si mesmo" (MÃE, 2016, p.103). É nesse contexto, e após jurar à mãe nunca mais lhe dar desgosto, que Antonino decide casar-se com Isaura. No entanto, como já sabido, na mesma noite do casamento ele abandona o novo lar e procura novamente a mãe. Essa lhe nega socorro, então, Antonino foge da cidade e tenta se matar no mar. Depois da tentativa fracassada de suicídio, sem ter para onde ir, resolve, após um mês de ausência, retornar a Isaura.

Aqui temos apresentados as quatro principais personagens da família que está prestes a ser inventada. A ligação de Isaura e Antonino, que se dá mais por afeto do que por papéis, já dá o tom dos alicerces que sustentarão essa nova entidade familiar. Os afetos, a compaixão, o amor, a fraternidade e a cumplicidade serão os fundamentos principais do novo lar, muito mais do que papéis, leis ou documentos.

O amor como uma predisposição natural para se ser a favor de outrem

Até a metade do romance, as personagens são todas apresentadas com essa marca de solidão e de exclusão social. O órfão Camilo, o solitário Crisóstomo, a enjeitada Isaura e o maricas Antonino, todos parecem "cair para dentro de si mesmos" - expressão que ilustra com poesia o estado depressivo de desinvestimento libidinal que Freud (1996/1917) atribui ao luto e à melancolia. Sem atermo-nos às distinções de cada um desses dois tipos clínicos, para a presente discussão basta-nos perceber apenas o caráter doentio de um retraimento da libido. Quando o sujeito fixa sua libido num circuito narcísico, não investindo suas pulsões no mundo externo, o mundo se torna empobrecido e o Eu tende a se deprimir. Freud reconhece esse retraimento da libido como uma defesa importante que nos protege de novas frustrações oriundas do mundo externo, o que a queda de Isaura para

\footnotetext{
${ }^{3}$ Em 2012, ano de publicação do romance de Mãe no Brasil, um relatório publicado pela Secretaria de Direitos Humanos da Presidência da República revelou que foram registradas mais de 3 mil denúncias de agressões contra o público LGBT, o que representou um aumento de mais de $160 \%$ em relação a 2011. Das denúncias, 32,68\% referiam-se à violência física. $\mathrm{O}$ relatório está disponível no site: http://www.sdh.gov.br/noticias/2013/junho/numero-de-denuncias-de-violencia-homofobica-cresceu-166em-2012-diz-relatorio. Acesso em: 08 jan. 2018.
} 
dentro de si ilustra muito bem. No entanto, o mesmo Freud percebe que deixar de investir no mundo externo pode nos jogar em um abismo interior muito grande que nos adoece:

Um egoísmo forte constitui uma proteção contra o adoecer, mas, num último recurso, devemos começar a amar a fim de não adoecermos, e estamos destinados a cair doentes se, em consequência da frustração, formos incapazes de amar (FREUD, 1996/1914, p.92).

As personagens parecem todas empreenderem essa luta entre uma proteção narcísica e uma inclinação ao risco do amor objetal. Todas parecem ter uma grande disposição para amar: Crisóstomo desejando um filho e uma mulher; Isaura um marido; Camilo com sua predisposição à gratidão; e Antonino com sua pulsão homossexual reprimida. No entanto, o mundo externo oferece frustações a todos eles, principalmente a Isaura e Antonino, nos quais pesa com mais força o perverso preconceito da vila. As personagens então caem para dentro de si abrindo mão de seus desejos e da capacidade de amar, sendo absorvidas por um circuito narcísico da libido. Camilo se tranca em casa após a morte do velho Alfredo, a quem ele chamava de avô. Isaura se isola em uma anorexia que tende a transformá-la em nada. E Antonino decide negar seu desejo sendo "herói de si mesmo" e, no auge da agonia, tenta se matar. O único que parece desde o início sentir-se seguro para lutar pelo seu desejo, possivelmente por sofrer menos com os preconceitos da vila, é Crisóstomo. E é justamente ele quem irá de certo modo resgatar nos demais a capacidade de amar, ensinando, às vezes de forma didática e professoral, o que é o amor: "Crisóstomo explicava que o amor era uma atitude. Uma predisposição natural para se ser a favor de outrem (...) Ser, sem sequer se pensar, por outra pessoa” (MÃE, 2016, p.122).

No entanto, para amar não basta haver libido. Pois, se amar é investir libido no mundo externo, no campo do Outro, faz-se minimamente necessário que o mundo externo tolere esse investimento. O que não acontece na vila, que só oferece como possibilidade de felicidade destinos libidinais predeterminados pela moral e pelos ideais rígidos da comunidade. Não é à toa que Freud, de maneira que lembra o texto de Mãe, afirma que a felicidade frequentemente é buscada através de um desprendimento dos ideais do mundo externo: "Tornar a ser seu próprio ideal, como na infância, no que diz respeito às tendências sexuais não menos do que às outras - isso é o que as pessoas se esforçam por atingir como sendo sua felicidade" (FREUD, 1996/1914, p.107).

Ou seja, a felicidade depende, também, de ideais menos proibitivos, que suportem as diferentes formas de amor, de desejo e de gozo dos seres humanos. Por isso, "ser seu 
próprio ideal", e com isso bancar seu desejo, independentemente dos ideais preconceituosos da vila, vira uma saída para as personagens que descobrem, juntas, destinos para a libido mais consoantes com seus desejos. No plano clínico, trata-se da fórmula que Lacan encontrou para a ética da psicanálise, que recomenda nunca cedermos de nossos desejos: "A única coisa da qual se pode ser culpado é de ter cedido de seu desejo" (LACAN, 1959-60/1997, p.385). E no plano social trata-se de uma questão de senso de justiça permitir que as pessoas encontrem distintas formas de satisfazer sua libido, logicamente respeitando a integridade e dignidade de seus semelhantes. Algo que Freud, no início do século passado, já intuía: "Uma das óbvias injustiças sociais é que os padrões de civilização exigem de todos uma idêntica conduta sexual" (FREUD, 1996/1908, p.177).

A forma como as quatro personagens resolverão o impasse em que se encontram revela como os padrões da civilização nem sempre estão preparados para absorver as variadas condutas não apenas referentes à sexualidade, mas também relacionadas a outras esferas da vida humana, como a família. Nesses casos, faz-se necessário uma invenção, como bem demonstra Mãe em O filho de mil homens.

A invenção surge de um impasse. Isaura sentiu que namorava Crisóstomo, mas sentia-se presa a Antonino por compaixão. Camilo reconhecia Crisóstomo como pai e se felicitava com a chegada de Isaura. No entanto, aprendeu com o avô que os "homens maricas" eram monstros que queriam "ensinar a humanidade a nascer pelo cu" (MÃE, 2016, p.118). Além disso, via Antonino como um obstáculo à felicidade de seu pai e, mais ainda, uma peça que não se encaixava no quebra cabeça da família que aprendeu a desejar:

O Camilo assim o aprendeu. Pensava que ia crescer no sentido mais clássico do presépio. Uma senhora, um senhor, um menino e os animais a verem contentes. Depois, os vizinhos em visita com oferendas. Um presépio limpinho (MÃE, 2016, p.119).

Um presépio limpinho, tal como propõe o Estatuto da Família apresentado por Anderson Ferreira. Acontece que nem sempre a família sai aos moldes de um presépio. E Antonino estava ali, sentado no sofá ao lado de Crisóstomo e Isaura para demonstrar isso a Camilo. No entanto, ao contrário do que costumeiramente ocorria na vila, a peça não encaixada no quebra-cabeças não foi resolvida com ódio, agressão, violência ou exclusão. Como se vê na segunda metade do romance, a família é inventada justamente ao encontrar para Antonino um lugar, ainda que inusitado, na nova entidade familiar. 
Uma família também se inventa

No início de seu namoro com o pescador, Isaura se viu como uma peça que se encaixava perfeitamente no quebra-cabeças de Crisóstomo e Camilo:

A Isaura namorava o Crisóstomo, que a sentava ao lado do boneco do sorriso de botões vermelhos e a apresentara ao Camilo. Os dois fizeram dela a peça de um quebra-cabeças ali encaixada (...) ela sentiu-se encaixar. A forma sumida do seu corpo era a matriz inequívoca da falta que existia naquela casa (MÃE, 2016, p.93).

Mas logo reaparece aquele que foi seu marido, um marido de poucos dias, já que o casamento foi anulado devido ao fato de o esposo ter abandonado o lar. Antonino reaparece como uma peça impossível de se encaixar no quebra-cabeças que estava prestes a se formar.

No entanto, Isaura, que poderia rejeitar essa peça não encaixável, destilando ódio e vingança pelo abandono, compadece do "homem maricas" e o acolhe. Reconhecendo a dor e o sofrimento do rapaz, ela passa a ter uma predisposição natural para ser a favor de Antonino. Em outras palavras, ainda que por compaixão, ela o ama, e por amor não o rejeita, mas o acolhe em um arranjo que ela mesmo reconhece como esdrúxulo: "Talvez por causa do amor, a Isaura permitiu que o Antonino ficasse em sua casa (...) Era uma situação esdrúxula que tivesse um homem dentro de casa" (MÃE, 2016, p.134-135). Esdrúxula, sobretudo, pelo fato de ela não romper seu namoro com Crisóstomo, que também aceitou e acolheu Antonino. Isaura, então, fica entre o pescador, que ela começa a amar, e "o homem maricas", que ela abriga em casa por compaixão.

Antonino, então, agrada-se da compaixão e aceita o lugar que lhe foi reservado no triângulo amoroso, quebra-cabeças que constituirá a futura família: "O Antonino ficava ali encaixado também, e o povo, sem saber se aquilo era marido ou disparate, haveria de habituar-se e calar-se devagarinho” (MÃE, 2016, p.135). Há finalmente um lugar para cada uma das personagens e a vila com seus "delirantes preconceitos" vai habituando-se com o modo de existir singular daquele grupo.

Em uma das cenas mais sensíveis do triângulo amoroso, Antonino ajuda Isaura a se enfeitar para Crisóstomo. Isaura se assusta com a beleza que o "homem maricas" encontra nela, "Nunca pensara que a beleza pudesse estar simplesmente como preguiçosa à sua mercê. À mercê de um maior empenho" (MÃE, 2016, p.136). Porém não se tratava apenas de empenho, mas também de um olhar que descobrisse uma vida que a tristeza de Isaura 
escondia. "O Antonino via a Isaura e sabia de algum modo onde estava escondida sua beleza. O Antonino via a Isaura.” (MÃE, 2016, p.136). Isaura sente-se feliz, absoluta, e pensa que talvez agora Antonino fosse um bom marido.

Ao se deparar com Isaura, investida da beleza que Antonino preparou, Crisóstomo pergunta se ela não vinha de noiva, se não estaria pronta para casar. O pescador agradece Antonino, diz que talvez ele seja o melhor ser humano do mundo, aquele que the deu o melhor presente. Aqui começa a invenção de uma nova família, um quebra-cabeças que se vai se construindo de forma bastante singular, como muitas vezes acontece na vida real. A mulher, que antes fora enjeitada, percebe logo isso: "A Isaura sorria e achava subitamente que as coisas se compunham a partir do que não seria óbvio” (MÃE, 2016, p.140).

Mas ainda havia o Camilo, que esperava uma família de presépio clássico, limpinho. Camilo havia aprendido com o velho Alfredo que o amor, como também quer o Estatuto da Família e outros discursos preconceituosos, "era todo da família ou dos homens com as mulheres" (MÃE, 2016, p.119). Não restava chances de amor aos homossexuais. No entanto, ao ver a felicidade do pai e a forma como ele acolhia Antonino, o menino começou a repensar os ensinamentos equivocados do avô. $\mathrm{O}$ avô, que lhe dissera que os livros eram tão potentes que deveriam ser capazes de curar doenças e controlar o colesterol, também lhe havia ensinado que os maricas são monstros. Agora Camilo começou a descobrir que os pensamentos valiam mais do que os livros: "Pensou assim e achou que, não sendo um livro, era um pensamento capaz de eliminar o colesterol" (MÃE, 2016, p.142).

Camilo talvez seja a personagem que melhor representa essa transformação que percebemos também no narrador do livro, em Matilde e em outras personagens. O discurso de Camilo, como também o do narrador, vai deixando de lado o preconceito e se abrindo para possibilidades várias de felicidade. Crisóstomo, que adiante é visto pelo filho como um pai herói, que salvava e amava toda a gente, estimula o rapaz nessa luta contra os preconceitos: "nunca limites o amor, filho, nunca por preconceito algum limites o amor" (MÃE, 2016, p.141).

Ainda assim, quando Isaura tem a ideia de fazer um jantar reunindo quase todas as personagens do livro, Camilo resiste. À pergunta de Antonino, se poderia misturar-se à família de Isaura, o rapaz, contrariando a mulher de seu pai, diz que não. Além de monstro, o menino vê em Antonino um obstáculo para o quebra-cabeças que ele, seu pai e a jovem 
mulher estavam construindo. Crisóstomo o repreende com um olhar: "O Crisóstomo nunca poderia bater no rapaz pequeno. Não o podia defraudar nos cuidados e no amor que lhe tinha, mas o olhar triste disse-lhe o quanto desaprovava o que dissera" (MÃE, 2016, p.182). Com o olhar, o pescador prosseguia seu ensinamento de que não se deve, por preconceito, limitar o amor. Ensinamento que seria muito útil também aos legisladores que se debruçam sobre o Estatuto da Família.

A despeito da reprovação do menino, o jantar sugerido por Isaura acontece e se revela um dos pontos altos do livro, uma espécie de fotografia inicial da família inventada. $\mathrm{Na}$ ceia estão presentes também Matilde, mãe de Antonino, Gemúndio, um velho que se casa com a caseira de Matilde, Mininha, filha da caseira, e um jovem do cerco amigo de Gemúndio. Matilde também havia inventado uma família. Com a morte da caseira, adotou Mininha e não tendo Gemúndio capacidade de administrar sua casa, adotou também o velho. A própria ideia do jantar é descrita como uma forma de Isaura misturar as duas famílias. Nesse sentido o jantar foi de fato eficaz. Crisóstomo foi um dos primeiros a notar as famílias inventadas que se misturavam em volta da mesa como em um carrossel, "disse que entre Isaura ser dele e do Antonino era importante que fossem todos familiarmente unidos. Farto como estava de ser sozinho, aprendera que a família também se inventava" (MÃE, 2016, p.184).

E no jantar, o lugar de Antonino naquele quebra-cabeças é terminantemente reconhecido, tanto por Matilde como pelo reticente Camilo. Matilde, que tanto maldisse a homossexualidade do filho, sentiu que, "por tolice ou vaidade", Antonino cabia naquela casa. Mais do que isso, a mãe de Antonino percebeu a injustiça social de se exigir de todos uma idêntica conduta. E corroborando o discurso já citado de Freud a respeito do assunto, prosseguiu em sua percepção:

sentiu que uma casa onde o seu menino grande pudesse caber haveria de ser uma casa perfeita. Com tanto desespero, pensou subitamente que o mundo poderia ser mais justo para com o seu menino diferente. $\mathrm{O}$ mundo poderia ser melhor (MÃE, 2016, p.184).

Também Camilo notou que havia sim espaço para Antonino naquele quebracabeças. Subitamente, o miúdo levantou-se no meio do jantar e, sem dizer nenhuma palavra, sorriu a Antonino. Mais tarde, sozinho em seu quarto, compreendeu o que os defensores do Estatuto da Família parecem desconhecer, "pensou que a família era um organismo todo complexo e variado. Era feita de tudo" (MÃE, 2016, p.188). Se a família 
era feita de tudo, então Antonino também poderia participar. Numa epifania poética, o rapaz de quatorze anos pensou que o Antonino estaria a fazer a parte do Antonino no coletivo, no todo. Quando procurou o pai para pedir desculpas pela rudeza dirigida ao antes chamado "homem maricas", o rapaz surpreendeu Crisóstomo ao se referir a Antonino como tio.

Nesse momento do romance, não há mais grandes obstáculos para as famílias de Crisóstomo e de Matilde. Estavam inventadas e misturadas, houvesse ou não um Estatuto que lhes reconhecessem. Isaura era esposa tanto de Crisóstomo como de Antonino. Pois mesmo guardando seu amor erótico para o pescador, não deixou de se referir ao outro como marido também, chegando mesmo a sentir orgulho do matrimônio: "A Isaura respirou, sorriu, depois disse que, em certo sentido, sentia orgulho por ter casado como Antonino” (MÃE, 2016, p.190). Camilo sentia-se, há muito, filho de Crisóstomo, e começava a aprender a tratar Isaura também como mãe, algo que será explicitamente reivindicado por ela no final do livro. Antonino era para ele o tio, que o ensinava delicadezas, ajudava nos cuidados da casa e dos bichos e enfeitava Isaura para o pescador. A família se misturava à família também inventada de Matilde, que assumiu a maternidade de Mininha e os cuidados de Gemúndio. Isaura, após lamentar no cemitério como a vida poderia ter sido mais fácil e melhor para ela e para a mãe, não fossem tantos preconceitos e submissões, reforça a disposição da nova entidade familiar para Mininha: "não estás sozinha, pequena, tens a mãe Matilde e a tia Isaura, tens o tio Antonino e o tio Crisóstomo, e ainda levas com o primo Camilo que te pode ajudar na escola (MÃE, 2016, p.183).

Também Camilo, no final do livro, diante de sua nova amiga Teresa, compreende a nova família: "o meu avô também morreu, e a minha avó já tinha morrido, e a minha mãe e o meu pai. E depois tive outro pai e agora vou ter uma mãe, e tenho um tio e mais a mãe do meu tio e a nova filha dela que fica a ser minha prima" (MÃE, 2016, p.205).

Uma família também se inventa, descobriu Crisóstomo; uma família é um organismo complexo e variado, intuiu Camilo. Por isso importa muito mais aos nossos governantes pensar nas variações e invenções de cada família, buscando fazer caber no quebra-cabeças das leis diferentes e complexas entidades familiares, do que limitar, através de um Estatuto, o arranjo familiar modelado pelo presépio limpinho com o qual sonhava Camilo. É também a posição de Lacan, já em 1938, que recomenda aos psicanalistas não temerem os novos arranjos familiares: "não estamos entre os que se afligem com um 
pretenso afrouxamento dos laços de família” (LACAN, 1938/2003, p.66). Lacan segue coerente aos estudos freudianos, que sempre buscaram fazer caber no Outro social a diferença, muito mais do que apostar em um tipo de exclusão. Freud, ao denunciar a injustiça social de exigir modos idênticos de satisfação, já havia demonstrado esse compromisso ético da psicanálise. Compromisso que se alinha ao pensamento de Camilo sobre Antonino e o todo. Antonino deveria fazer as vezes de Antonino no todo. Da mesma forma, a família de Camilo fará também as vezes da família de Camilo no todo. Cada um faz sua parte singular no todo universal.

\section{A familia do futuro deve ser mais uma vez reinventada}

Em seus estudos sobre o desenvolvimento do conceito de família no discurso ficcional de Valter Hugo Mãe, Danilo Sales de Queiroz Silva recupera o argumento da psicanalista francesa Elisabeth Roudinesco e declara que os golpes que famílias inventadas, como a de Crisóstomo, causam na ordem simbólica, nada têm a ver com a tentativa da supressão da família, "mas sim a iniciativa, de grupos anteriormente excluídos dessa ordem, de se integrarem a ela" (SILVA, 2017, p.55). De fato, a conclusão a que chega Roudinesco após um longo debate sobre a história e os impactos dos novos arranjos familiares na cultura é que a família continua sendo reivindicada "como o único valor seguro ao qual ninguém quer renunciar. Ela é amada, sonhada e desejada por homens, mulheres e crianças de todas as idades, de todas as orientações sexuais e de todas as condições" (ROUDINESCO, 2003, p.198). Ou seja, ao invés da extinção da família, assistimos na verdade o pleito de sua expansão. Como Lacan, Roudinesco também recomenda não cedermos aos discursos apocalípticos que profetizam a destruição e a decadência da família:

Para aqueles que temem mais uma vez sua destruição ou sua dissolução, objetamos, em contrapartida, que a família contemporânea, horizontal e em redes, vem se comportando bem e garantindo corretamente a reprodução das gerações (ROUDINESCO, 2003, p.197).

Portanto, ainda que os estudos psicanalíticos sobre Édipo possam, como lembra Silva (2017), ter servido de argumentos para alguns defensores de um ideal tirânico de família sustentado na "triangulação edipianizante", a psicanálise, de modo geral, rechaça a ideia de que novas configurações familiares representam uma ameaça à família. Mais consoante com a ética da psicanálise está a posição freudiana de que é uma injustiça social 
exigir uma normatividade e uniformidade absoluta dos seres humanos. Daí as últimas palavras do livro A familia em desordem, de Elisabeth Roudinesco, serem quase as mesmas de Crisóstomo: "A família do futuro deve ser mais uma vez reinventada" (ROUDINESCO, 2003, p.199).

Assim, seja com Freud (1996/1930, p.118), que diz que a família é a "célula germinal da civilização", ou com Lacan (1938/2003, p.30), que situa a família como grupo humano que "desempenha um papel primordial na transmissão da cultura", ou ainda com Miller (2007, p.04), que define a família como um mito ou um conto que dá forma épica à estória de "como o gozo que o sujeito merecia lhe foi subtraído", não teríamos muitos motivos para temer o fim da família como sugere o projeto de lei de Anderson Ferreira. Pois o grande Outro, simbólico, morada do significante, permanece sendo representado por pequenos outros, imaginários, que compõem os membros de uma família, uma célula germinal da civilização, um grupo humano transmissor da cultura. Ainda que se mude a forma de organização social para a constituição do sujeito, permanece sempre esse mito que dá forma épica à estória de cada um.

A família, nesse sentido, não é um organograma com papéis previamente definidos. A família é uma rede de afetos que abriga uns aos outros e forma laços que dão a todos uma sensação de pertencimento e faz com que a solidão de cada um se ligue a um grupo, protótipo da civilização como um todo. A família, nos dizeres de Crisóstomo, mais do que um organograma, é encontro e pertença: "Acreditou que o afecto verdadeiro era o único desengano, a grande forma de encontro e de pertença. A grande forma de família" (MÃE, 2016, p20).

Diante do exposto, quase poderíamos desprezar o tal Estatuto dizendo que as famílias continuarão se inventando, que as pessoas continuarão se pertencendo, como sempre se inventaram, como sempre se pertenceram, independente do que o governo determine. Parafraseando Isaura, que no início da trama sente que a vida se fazia à revelia da felicidade, poderíamos dizer que as famílias também se fazem à revelia do governo. Embora isso seja verdade, também é verdade que o Estado reconhecer ou não um grupo como família não é indiferente. Por isso, dizer, com Lacan e Camilo, que não devemos temer os novos arranjos familiares, por mais complexos e variados que sejam, não pode significar dizer que a família não precise de amparos do Estado, nem que sejam desnecessárias leis que regulem processos de adoção e constituição de novas famílias. Pelo 
contrário, a família ser um organismo complexo, que se inventa à revelia do Governo, demanda, por vezes em forma de lutas e reivindicações, que o Estado ampare mais famílias, mesmo aquelas que fujam do conceito que o deputado sugeriu em seu Estatuto - ou que Camilo sonhava a partir do presépio. Daí a importância de a sociedade acompanhar um projeto de lei como esse e cobrar dos legisladores que variadas formações familiares sejam contempladas.

Consideracõos finais

A trama prossegue com a nova família se consolidando cada vez mais, o que vai ajudando a compor um verdadeiro happy ending. Essa proposta de reconciliação e partilha das personagens pode causar espécie a alguns leitores, como bem observou Paulo Ricardo Kralik Angelini,

E o que torna possível esse compartilhar de sentimentos ao mesmo tempo causa um estranhamento ao leitor, tão acostumado estamos com a literatura que mergulha na crise, no trágico, no sofrimento. Falar sobre situações belas na simplicidade que as compõe, em cenas que abraçam a afeição, nos nossos tempos, pode soar antiquado, incoerente, inverossímil, mesmo infantil (ANGELINI, 2012, p.247).

A despeito do estranhamento, o happy end vai se impondo. Crisóstomo pede Isaura em casamento, Mininha reconhece Matilde como mãe e Gemúndio tem uma morte serena. Camilo encontra uma amiga cujo irmão se matou por ser "diferente" e o medo de o tio seguir o mesmo caminho faz o rapaz amar ainda mais Antonino. Esse, por sua vez, se aproxima de um homem desconhecido, que aparece no final do livro como uma espécie de deus ex machina, o que realça a impressão de happy end. O lugar de Antonino no quebracabeças não se limita mais a enfeitar Isaura para o amor de outro. Reconciliando-se com seu desejo, ele também acaba encontrando um lugar na esfera do amor erótico. O homem desconhecido, contrariando o estereótipo que a vila tinha dos "maricas", não chora facilmente nem é muito delicado. Sendo o que é, recebe e é recebido por Antonino, também agora sendo o que é.

Por mais harmônico que seja o final do livro, é importante dizer que, como sugere novamente Angelini em outro artigo, a narrativa de Mãe permanece "longe de uma ingenuidade utópica, longe de um carolismo familiar, que é aquela que inicia na concepção clara de que somos seres sociais e, portanto, nascemos para viver em conjunto" 
(ANGELINI, 2015, p.24). A narrativa de Mãe aponta mais para um argumento filosófico de que estamos a tudo conectados do que a um moralismo que pleiteia a harmonia e a união de todos. Isso se torna explícito na reflexão de Crisóstomo que dá nome ao romance: “todos nascemos filhos de mil pais e de mil mães, e a solidão é sobretudo a incapacidade de ver qualquer pessoa como nos pertencendo, para que nos pertença de verdade e se gere um cuidado mútuo" (MÃE, 2016, p.204-205).

Não se trata de pregar a vida em harmonia ou em conjunto, mas de reconhecer que fazemos, cada um com suas especificidades, parte de um todo. E que a solidão, provocada por vezes pela exclusão social, é resultado do não reconhecimento dessa ligação inevitável com o mundo. Não percebendo essa ligação, ou sendo impedido de percebê-la, caímos para dentro de nós. Para usar novamente a teoria de Freud (1920/1996), o que ocorre é que se não investimos pulsão de vida (Eros) nos objetos do mundo, a pulsão de morte impera. Daí as personagens iniciarem a história caindo para dentro de si, já que a pulsão de morte age "silenciosamente dentro do organismo, no sentido de sua destruição" (FREUD, 1930/1996, p.123). Excluídas socialmente e oprimidas pela vila, cada uma delas tomba para seu próprio interior.

Camilo é, novamente, um dos melhores exemplos do rapaz que, solitário diante de sua segunda orfandade, caía para dentro do rapaz e que, ao perceber-se pertencente a uma nova família, começa a se levantar: "Também ele tinha um tamanho cada vez mais infinito. E não caía. Sentia que levantava" (MÃE, 2016, p.191). Esse erguimento de Camilo descrito no final do livro ocorre com quase todos os personagens, que ganham tamanhos infinitos, poéticos e se levantam. No entanto, eles não rejeitam o passado difícil, as dores e o preconceito sofrido. A felicidade se apresenta não como uma substituição da dor pelo júbilo, mas como algo que se soma ao sofrimento: "Eram, tanto quanto possível, os felizes. Porque a felicidade não se substituía ao resto, a felicidade acumulava-se" (MÃE, 2016, p.191). Por isso Crisóstomo recomenda nunca cultivar a dor, mas ao mesmo tempo não deixar de guardá-la com carinho e respeito: "Deve nutrir-se carinho por um sofrimento sobre o qual se soube construir a felicidade” (MÃE, 2016, p.187). Não é por acaso que Valter Hugo Mãe descreve a cena do jantar como um momento que as personagens celebravam, sobre as dores de cada uma, as partilhas. Pois foi a partir dessa história de dores, preconceitos e solidões, que a família foi inventada. Mas o resultado da invenção foi a partilha e, mais do que isso, o pertencimento. Nossos legisladores deveriam se sensibilizar 
para esse fato de que a família se sustenta muito mais pelo o que seus membros partilham do que pelo o que são enquanto gênero ou consanguinidade. À revelia dos graus de parentescos e da disposição de gênero recomendada pelo presépio limpinho de Camilo e do Estatuto da Família, o livro termina reafirmando a invenção singular da entidade familiar e reforçando o papel do pertencimento nessa configuração: "Pertenciam-se e comunicavam entre si pela intensidade dos sentimentos. Tinham inventado uma família" (MÃE, 2016, p.216).

No entanto, para que nossos legisladores sejam tocados pela poesia dessa família inventada, e de tantas famílias que se inventam e se reinventam no cotidiano do nosso país, primeiro teriam que se dar conta, como se deu Camilo, de que a vida é "aprender, saber sempre mais e mudar para aceitar sempre mais" (MÃE, 2016, p.191). Porque se eles não compreenderem que as leis e os Estatutos também devem buscar aceitar sempre mais, continuarão como os pescadores que não entendiam que a vida de Crisóstomo era diferente, porque não sabiam que "esperar que a vida de toda gente fosse igual era uma rotunda estupidez" (MÃE, 2016, p.141). 


\section{Bibliografia}

ANGELINI Paulo Ricardo Kralik. Por uma teorização do afeto: uma leitura de Ribamar, de José Castello, e O filho de mil homens, de Valter Hugo Mãe. Nonada, Porto Alegre, n.25, p.14-26, jul./dez. 2015.

ANGELINI Paulo Ricardo Kralik. Recensão de O filho de mil homens. Navegações, Porto Alegre, v.5, n.2, p.247-249, jul./dez. 2012.

BEUTTENMULLER, Eric. Fraternidade de mil homens. Revista Desassossego, São Paulo, n.8, p.187-191, dez. 2012.

BRASIL. Câmara dos Deputados. Projeto de lei 6583/13, 2013. Dispõe sobre o Estatuto da Família e dá outras providências. Disponível em: http://www.camara.gov.br/proposicoesWeb/fichadetramitacao?idProposicao $=597005$.

Acesso em: 04 jan. 2018.

BROWN, Wendy. Regulating Aversion: Tolerance in the Age of Identity and Empire. Princeton, Princeton University Press, 2006 citado por ZIZEK, Slavoj. Violência. São Paulo: Boitempo, 2014.

COSTA E SILVA, Fagner. O filho de mil homens e a construção da família moderna. Revista Pontos de Interrogação, Alagoinhas, v.7, n.1, p.193-198, jan.-jun. 2017.

FREUD, Sigmund. Além do princípio do prazer. In FREUD, Sigmund. Edição Standard das Obras Psicológicas Completas de Sigmund Freud: Volume XVIII (originalmente publicado em 1920). Rio de Janeiro: Imago, 1996, p. 13-78.

FREUD, Sigmund. Luto e Melancolia. In FREUD, Sigmund. Edição Standard das Obras Psicológicas Completas de Sigmund Freud: Volume XIV (originalmente publicado em 1917). Rio de Janeiro: Imago, 1996, p.243-266.

FREUD, Sigmund. Moral sexual civilizada e doença nervosa moderna. In FREUD, Sigmund. Edição Standard das Obras Psicológicas Completas de Sigmund Freud: Volume IX (originalmente publicado em 1908). Rio de Janeiro: Imago, 1996, p.165-186.

FREUD, Sigmund. O mal-estar na civilização. In FREUD, Sigmund. Edição Standard das Obras Psicológicas Completas de Sigmund Freud: Volume XXI (originalmente publicado em 1930). Rio de Janeiro: Imago, 1996, p.66-148.

FREUD, Sigmund. Sobre o narcisismo: uma introdução. In FREUD, Sigmund. Edição Standard das Obras Psicológicas Completas de Sigmund Freud: Volume XIV (originalmente publicado em 1914). Rio de Janeiro: Imago, 1996, p.75-108.

FREUD, Sigmund. Três ensaios sobre a teoria da sexualidade. In FREUD, Sigmund. Edição Standard das Obras Psicológicas Completas de Sigmund Freud: Volume VII (originalmente publicado em 1905). Rio de Janeiro: Imago, 1996, p.117-231.

LACAN, Jacques. O Seminário, livro 7: a ética da psicanálise (originalmente proferido em 1959-60). Tradução de Antonio Quinet. Rio de Janeiro: Jorge Zahar, 1997.

LACAN, Jacques. Os complexos familiares na formação do indivíduo. In: LACAN, Jacques Outros Escritos (originalmente escrito em 1938). Tradução de Vera Ribeiro. Rio de Janeiro: Jorge Zahar, 2003.

MÃE, Valter Hugo. O filho de mil homens. São Paulo: Biblioteca Azul, 2016. 
MILLER, Jacques-Alain. Assuntos de famílias no inconsciente. Tradução de Tania Coelho dos Santos. Revista eletrônica do Núcleo Sephora, v.2, n.4, mai./out., 2007.

ROUDINESCO, Elizabeth. A família em desordem. Tradução de André Telles. Rio de Janeiro: Jorge Zahar Ed., 2003.

SARTRE, Jean-Paul. Entre quatro paredes. Tradução de Alcione Araújo e Pedro Hussak. Rio de Janeiro: Civilização Brasileira, 2009.

SILVA, Danilo Sales de Queiroz. A grande forma de família: em defesa de uma família inventada. Revista Légua e Meia, Feira de Santana, v.8, n.1, p.53-65, 2017.

ZIZEK, Slavoj. Violência. Tradução de Miguel Serras Pereira. São Paulo: Boitempo, 2014. 